\title{
Physiological effects of Pekilo single cell protein on pigs
}

\author{
Ritva Järvinen, Raija Savonen and Antti Ahlström \\ Department of Nutrition, University of Helsinki, 00710 Helsinki 71 \\ Timo Alaviuhrola \\ Swine Research Station, Agricultural Research Centre, 05840 Hyvinkää 4
}

\begin{abstract}
The physiological effects of Pekilo microfungus biomass (Paecilomyces varioti) grown in sulphite spent liquor solution was studied in pigs.

Sixteen Finnish landrace gilts weighing about $22 \mathrm{~kg}$ were divided into two groups of eight animals each. The animals were fed a barley- and oat-based diet supplemented with vitamins and minerals. The soybean and fish meal mixture used as a protein supplement for the control group was replaced with Pekilo at a level of $13 \%$ of the feed weight in the experimental diet used up till farrowing. The experimental diet used during lactation contained $15 \%$ of Pekilo. The feed consumption and weight gain of the animals were recorded. The experiment lasted almost one year and included the growth, gestation and lactation periods of the sows. The weight gain of the piglets was observed. After weaning of the litter the sows were analysed for blood haemoglobin, haematocrit and white blood cell count, plasma glucose, serum bilirubin, ASAT, ALAT, urea, uric acid, allantoin, total protein and albumin/globulin ratio. The allantoin, uric acid and creatinine contents of a single urine sample were determined quantitatively, and the $\mathrm{pH}$, glucose and protein contents semiquantitatively. The urine density was measured.

There were no significant differences between the two groups with regard to weight gain, feed consumption, feed efficiency and reproductive performance. Serum urea and plasma glucose levels were significantly lower in the Pekilo-fed group than in the control group but were within the normal limits for swine. The serum allantoin level and the urine allantoin/creatinine ratio of the Pekilo group were significantly above the control group values. No differences were found between the two groups in the other blood and urine analyses.

The use of Pekilo biomass as protein supplement in the diet of breeding sows was found to have no detrimental effects as assessed on the basis of weight gain, feed consumption, feed efficiency, reproductive performance and certain blood and urine parameters.
\end{abstract}

\section{Introduction}

To help to alleviate the world-wide shortage of proteins new single cell products have been developed. Detailed recommendations for the study of the harmlessness of new protein products were drawn up by the Protein-Calorie Advisory Group (PAG) composed of representatives of United Nations organi- 
zations (PAG 1972). This Group was dissolved at the end of 1977. In the United States all single cell protein products must fulfill the Food and Drug Administration (FDA) requirements on food additives.

Pekilo biomass was developed in Finland and is produced at the Jämsänkoski Mill of the United Paper Mills Ltd. by growing the microfungus Paecilomyces varioti in sulphite spent liquor solution (Romantschuк 1975). Protein content of the Pekilo mass varies somewhat according to the growth rate of the organism. In industrial production the crude protein content of Pekilo seems to stay near to $\mathbf{5 0} \%$ of dry matter (SALO 1979). Pekilo mass additionally contains, on dry matter basis, 32-36\% carbohydrates, mostly hemicellulose (SALO 1977), and $2-4 \%$ fat (ether extract) as well as minerals and B vitamins (Romantschuk 1975, Salo 1979). The nucleic acid content of Pekilo is 10 to $11 \%$ of dry matter (SALo 1979).

In order to determine the nutritional properties of Pekilo numerous shortterm experiments have been carried out on rats, pigs, calves and chickens (Ahlström et al. 1968, 1969, Lampila et al. 1971, Poutiainen 1973, LAKsesvela and Slagsvold 1974, Alaviuhkola et al. 1975, Farstad et al. 1975, Barber et al. 1977). Experiments on the suitability of Pekilo as animal feed performed in nine different countries were reviewed in the International Pekilo Symposium held in 1978 (Kirskinen 1979). The addition of Pekilo to livestock feed was approved in Finland in 1971 (cf. Forss 1974). Its acceptability for human concumption still requires much research work, particularly as regards its long term effects.

The long-term experiment into the effects of Pekilo on the reproductivity of sows being carried out at the Swine Research Station of the Agricultural Research Centre, Hyvinkää, provided an opportunity for obtaining additional information about the effects of relatively long-term feeding of Pekilo biomass on the general condition, liver, kidneys and protein metabolism of swine.

\section{Material and methods}

Sixteen Finnish landrace gilts, 9 to 12 weeks old, were divided into two groups of eight animals each. The pigs were born at the Swine Research Station between December 9, 1976 and January 6, 1977. At the beginning of the experiment the average weight of the control group animals was $22.4 \mathrm{~kg}$ and of the experimental group $22.2 \mathrm{~kg}$. They were fed at first in groups of four, and later of two animals. During gestation and lactation the sows were fed individually. Weight gain was followed by weekly weighings. Breeding was begun when the sows weighed $100 \mathrm{~kg}$, at an age of about 7 months, using Finnish landrace boars. The piglets were weighed as newborn and at 3 and 5 weeks. From the age of 1 week onwards they had free access to the sow's feed mixture. The litter was weaned when 5 weeks old.

The barley- and oat-based control diet was supplemented with fish meal and soybean meal. A small amount of skim milk powder was added to the control diet during lactation. In the experimental diet Pekilo biomass was the source of supplementary protein. Table 1 shows the basic composition of Pekilo biomass and Table 2 the composition of the feed mixtures. The first batch of 
Pekilo lasted for about half of the test period, after which Pekilo mass B was used. The control diet and Pekilo diet were similar in crude protein, crude fat and crude fibre contents as well as energy sources. The animals were fed twice daily. Daily rations were gradually increased from $0.7 \mathrm{~kg}$ per animal at the beginning to $2.7 \mathrm{~kg}$ per animal after fifteen weeks. The animals had free access to water.

Table 1. Basic composition of Pekilo biomass. ${ }^{1}$

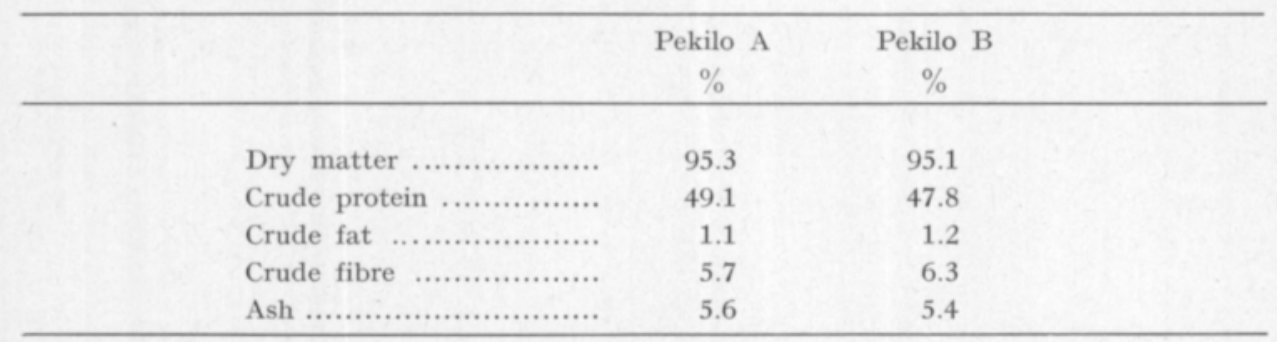

1 Research result certificates nr. 60/77 and 61/77 of the State Institute of Agricultural Chemistry, Helsinki.

Table 2. Composition of experimental diets during growth, gestation and lactation of the pigs.

\begin{tabular}{|c|c|c|c|c|}
\hline & \multicolumn{2}{|c|}{ During growth and gestation } & \multicolumn{2}{|c|}{ During lactation } \\
\hline & $\begin{array}{c}\text { Control diet } \\
\%\end{array}$ & $\begin{array}{c}\text { Pekilo diet } \\
\%\end{array}$ & $\begin{array}{c}\text { Control diet } \\
\%\end{array}$ & $\begin{array}{c}\text { Pekilo diet } \\
\%\end{array}$ \\
\hline Barley ..... & 42,0 & 41,0 & 42,0 & 40,8 \\
\hline 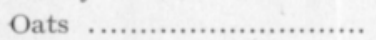 & 42,0 & 41,0 & 41,2 & 40,0 \\
\hline Soybean meal ................... & 5,0 & - & 5,0 & - \\
\hline Fish meal ...................... & 6,0 & - & 5,0 & - \\
\hline Skim milk powder .......... & - & - & 3,0 & - \\
\hline Pekilo ............................... & - & 13,0 & - & 15,0 \\
\hline Mineral mixture ${ }^{1}$............. & 2,0 & 2,0 & 2,0 & 2,0 \\
\hline Vitamin mixture $^{2}$........... & 1,0 & 1,0 & 0,5 & 0,5 \\
\hline Sodium chloride ............... & 0,2 & 0,2 & 0,1 & 0,1 \\
\hline Fodder phosphate ........... & 1,8 & 1,5 & - & - \\
\hline Dicalcium phosphate ...... & - & - & 1,0 & 1,0 \\
\hline Ground limestone ............ & - & 0,3 & 0,2 & 0,6 \\
\hline
\end{tabular}

1 KULTA-TUOTOS, Hankkija

2 DEBA-VITAN, Farmos

Blood and urine samples were taken from the sows on the fifth day after weaning of the litter. The blood sample was drawn from the ear vein with an injection needle $3-4$ hours after morning feeding. The single urine sample was collected when the animals urinated.

The blood haemoglobin was determined as cyanmethaemoglobin (VAN KAMPEN and ZIJLSTA 1961) and the haematocrit by centrifuging ((Microhematocrit centrifuge, Clay-Adams, Inc.) the blood in a capillary tube. White 
blood cells were counted mechanically (Coulter Counter, Model ZF, Coulter Electronic Ltd.) in $1 \%$ acetic acid and the differential count was made from blood smears stained by the May-Grünwald-Giemsa method (Hyvärinen et al. 1972). The glucose was determined from plasma (Sснмidt 1961). Bilirubin (JENDRASSIK and GROF 1938), ASAT, ALAT (ANON .1974), urea (FAWCETT and Scott 1960), uric acid (Kageyama 1971), total protein (Weichselbaum 1946) using commercial test combinations (Boehringer Mannheim GmbH, Mannheim) and allantoin (Sumi et al. 1976) were determined from the serum. The albumin/globulin ratio was calculated following electrophoretic fractionation of the serum protein in SDS polyacrylamide gel (FEHRNSTRöm and Moberg 1977) (LKB, Bromma 2117 Multiphor). The intensity of the stained protein fractions was measured with a densitometer (Digiscreen Scanner $R$, Gelman, Model 39381).

The presence of glucose and protein in the urine and the urine $\mathrm{pH}$ were determined with test strips (Combur 8 Test, Boehringer Mannheim GmbH, Mannheim). Urine density was measured with an areometer. The uric acid and allantoin contents of the urine were determined by the same methods as for serum. The creatinine content of the urine (CLARK and THOMPSON 1949) was determined for calculations of the uric acid/creatinine and allantoin/ creatinine ratios. A spectrophotometer (Perkin Elmer Double Beam, Model 124) and a fluorescence spectrophotometer (Perkin Elmer, Model 203) were used for the spectrophotometric and fluorometric measurements, respectively.

The mean and the standard error of the mean (SEM) were calculated from the results. The significance of differences between groups was tested with the Student's t-test.

\section{Results}

Table 3 shows the mean weight gain and feed efficiency (feed consumption in $\mathrm{kg} /$ weight gain in $\mathrm{kg}$ ) in the Pekilo and control groups during the first 19 weeks of the experiment. There were no statistically significant differences between the groups as regard to the weight gain of the animals or their feed utilization.

The breeding data of the sows are presented in Table 4. Some matings had to be repeated in both groups, and one sow in the Pekilo group did not become pregnant in spite of several matings. Histopathological examination of the ovaries, uterus, liver, heart and kidneys (Department of Pathology, State Veterinary Medical Institute, Helsinki) did not reveal any changes that could account for the failure to conceive. The mean age of the animals at the time of conception was 266 days in the control group and 261 days in the Pekilo group. There were no significant differences between the two groups with regard to the number of newborn piglets, birth weight, perinatal mortality, or weight gain of piglets during suckling. No external malformations were evident. Mortality before the age of 5 weeks was $11 \%$ in the control group and $17 \%$ in the Pekilo group. Most deaths occurred during the first few days after birth. Farrowings were not observed, which is normal practice at the station. One of the Pekilo group sows acquired mammitis and three piglets in 
Table 3. Initial weights of the pigs and their weights after 19 weeks on the experimental diets as well as daily weight gains and feed efficiencies of the animals.

\begin{tabular}{|c|c|c|c|c|}
\hline \multirow[b]{2}{*}{ Number of animals .................. } & \multicolumn{2}{|c|}{$\begin{array}{l}\text { Control group } \\
\mathrm{M} \pm \mathrm{SEM}\end{array}$} & \multicolumn{2}{|c|}{$\begin{array}{l}\text { Pekilo group } \\
\mathrm{M} \pm \mathrm{SEM}\end{array}$} \\
\hline & 8 & & 8 & \\
\hline 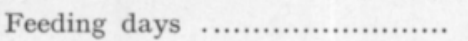 & 133 & & 133 & \\
\hline Initial weight, $\mathrm{kg} \quad \ldots \ldots \ldots \ldots \ldots \ldots \ldots$ & 22.4 & 1.1 & 22.2 & 0.8 \\
\hline Weight after 19 weeks, $\mathrm{kg} . \ldots \ldots .$. & 106.8 & 2.5 & 104.4 & 2.4 \\
\hline Daily gain, $g$....................... & 634 & 13 & 618 & 16 \\
\hline Feed efficiency (kg feed $/ \mathrm{kg}$ gain) & 3.6 & 0.5 & 3,8 & 0.6 \\
\hline
\end{tabular}

Table 4. Number and weight of piglets as newborn and at the age of 3 and 5 weeks.

\begin{tabular}{|c|c|c|c|c|}
\hline \multirow[b]{2}{*}{ Number of sows $\ldots \ldots \ldots \ldots \ldots \ldots \ldots \ldots \ldots$} & \multicolumn{2}{|c|}{$\begin{array}{l}\text { Control group } \\
\mathrm{M} \pm \mathrm{SEM}\end{array}$} & \multicolumn{2}{|c|}{$\begin{array}{l}\text { Pekilo group } \\
\mathrm{M} \pm \mathrm{SEM}\end{array}$} \\
\hline & 8 & & 7 & \\
\hline Number of newborn pigs $\ldots . \ldots \ldots \ldots . .$. & 9.0 & 1.1 & 7.6 & 1.0 \\
\hline Number of alive pigs at birth ........ & 8.9 & 1.0 & 7.3 & 1.0 \\
\hline 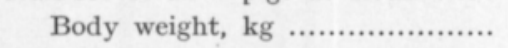 & 1.5 & 0.1 & 1.5 & 0.1 \\
\hline Number of alive pigs at 3 weeks ... & 8.1 & 1.0 & 6.4 & 0.9 \\
\hline Body weight, $\mathrm{kg} . . . \ldots \ldots \ldots \ldots \ldots . . . . .$. & 6.0 & 0.3 & 6.6 & 0.4 \\
\hline Number of alive pigs at 5 weeks ... & 8.0 & 1.0 & 6.3 & 0.9 \\
\hline Body weight, $\mathrm{kg} \ldots \ldots \ldots \ldots \ldots \ldots \ldots \ldots \ldots \ldots \ldots$ & 9.5 & 0.4 & 10.7 & 0.7 \\
\hline
\end{tabular}

Table 5. Blood analysis of the sows.

\begin{tabular}{|c|c|c|c|c|c|c|c|}
\hline \multirow[b]{2}{*}{ Haemoglobin $\mathrm{mg} / 100 \mathrm{ml}$} & \multicolumn{2}{|c|}{$\begin{array}{l}\text { Control group } \\
\mathrm{M} \pm \mathrm{SEM}\end{array}$} & \multicolumn{2}{|c|}{$\begin{array}{c}\text { Pekilo group } \\
\mathrm{M} \pm \mathrm{SEM}\end{array}$} & \multicolumn{2}{|c|}{ Normal value } & \multirow{2}{*}{$\begin{array}{c}\text { Reference }^{3} \\
(26)\end{array}$} \\
\hline & 12.2 & 0.5 & 12.0 & 0.4 & 10 & -16 & \\
\hline Haematocrit \% & 37 & 1 & 38 & 2. & 32 & -50 & $(26)$ \\
\hline White blood cells, $10^{9} / 1$ & 18.8 & 1.9 & 16.8 & 2.1 & 11 & -22 & (26) \\
\hline \multicolumn{8}{|l|}{ Neutrophils } \\
\hline Band & 6 & 2 & 7 & 2 & 1 & & (26) \\
\hline Segmented & 40 & 4 & 48 & 4 & 28 & -47 & (26) \\
\hline Eosinophils \% & 4 & 1 & 3 & 1 & 1 & -11 & (26) \\
\hline Basophils \% & 1 & 0 & 1 & 0 & 0 & -2 & (26) \\
\hline Monocytes \% & 4 & 1 & 5 & 1 & 2 & -10 & (26) \\
\hline Lymphocytes \% & 45 & 4 & 37 & 3 & 39 & -62 & (26) \\
\hline Glucose $\mathrm{mg} / 100 \mathrm{ml}$ & 86 & 3 & 73 & 2 & 65 & -95 & ( 8 ) \\
\hline ASAT U/1 & 21 & 2 & 21 & 1 & 31 & \pm 14 & (28) \\
\hline ALAT U/1 & 29 & 1 & 28 & 1 & 27 & \pm 8 & (28) \\
\hline Bilirubin $\mathrm{mg} / 100 \mathrm{ml}$ & 0.17 & 0.03 & 0.18 & 0.02 & 0 & -0.4 & (28) \\
\hline Urea $\mathrm{mg} / 100 \mathrm{ml}$ & 30.0 & 1.4 & 24.1 & 1.9 & 8 & $-24^{1}$ & ( 7$)$ \\
\hline Uric acid $\mathrm{mg} / 100 \mathrm{ml}$ & 0.2 & 0.1 & 0.3 & 0.1 & 0.05 & -1.95 & (28) \\
\hline Allantoin $\mathrm{mg} / 100 \mathrm{ml}$ & 0.9 & 0.1 & 1.3 & 0.1 & & & \\
\hline Total protein $\mathrm{g} / 100 \mathrm{ml}$ & 7.0 & 0.1 & 6.8 & 0.1 & 7.9 & -10.3 & $(28)$ \\
\hline Albumin $\%$ & 42 & 1 & 40 & 2 & 2.1 & $-4.6^{2}$ & (28) \\
\hline Globulin \% & 58 & 1 & 60 & 2 & & & \\
\hline Albumin/globulin ratio .... & 0.73 & 0.03 & 0.68 & 0.05 & & & \\
\hline
\end{tabular}

1 urea nitrogen $=17-51 \mathrm{mg}$ urea $/ 100 \mathrm{ml}$

$2 \mathrm{mg} / 100 \mathrm{ml}$

3 The number in brackets indicates the references in alphabetic order. 
Table 6. Quantative urine analysis of the sows.

\begin{tabular}{|c|c|c|c|c|}
\hline \multirow[b]{2}{*}{ Uric acid $\mathrm{mg} / 100 \mathrm{ml} \ldots \ldots \ldots \ldots \ldots \ldots$} & \multicolumn{2}{|c|}{$\begin{array}{l}\text { Control group } \\
\mathrm{M} \pm \mathrm{SEM}\end{array}$} & \multicolumn{2}{|c|}{$\begin{array}{c}\text { Pekilo group } \\
\mathrm{M} \pm \mathrm{SEM}\end{array}$} \\
\hline & 11.1 & 3.6 & 10.4 & 5.0 \\
\hline Allantoin $\mathrm{mg} / 100 \mathrm{ml}$................... & 31 & 8 & 36 & 10 \\
\hline Creatinine $\mathrm{mg} / 100 \mathrm{ml} \ldots \ldots \ldots \ldots \ldots \ldots$ & 65 & 17 & 52 & 16 \\
\hline Uric acid/creatinine ratio .............. & 0.17 & 0.02 & 0.17 & 0.30 \\
\hline Allantoin/creatinine ratio $\ldots \ldots \ldots \ldots \ldots$ & 0.50 & 0.02 & 0.77 & 0.10 \\
\hline
\end{tabular}

her farrow died, evidently from starvation. The farrow was partly on artificial feed (Plasma Nasu, Hankkija) and the pigs were weaned at the age of 4 weeks.

The blood analysis results of the sows in the two groups are given in Table $\mathbf{5}$. The normal blood values of swine are included for comparison purposes. These data, however, should be accepted with some reservation in view of differences in the methods of analysis and in the pysiological condition of the animals tested. Significant differences between the control and Pekilo groups were not found for the blood haemoglobin and haematocrit values, the white blood cell count, serum ASAT and ALAT activities, bilirubin, uric acid and total protein contents or in the albumin/globulin ratio. The glucose content of the plasma of the sows given Pekilo was significantly $(\mathrm{P}<0.01)$ lower than that of the control group animals. The serum urea content was also significantly $(\mathrm{P}<0.05)$ lower and the allantoin content higher $(\mathrm{P}<0.01)$ than than in the control group.

The urine $\mathrm{pH}$ of all the animals was about 5. Protein was not found in the urine samples. Glucose was present in moderate amounts in the urine of two control animals and abundantly in the urine of one Pekilo animal. There was considerable individual variation in the urine density, but the group values did not differ significantly. The mean of the urine density was $\mathbf{1 . 0 0 9}$ $\mathrm{g} / \mathrm{cm}^{3}$ in the control group and $1.008 \mathrm{~g} / \mathrm{cm}^{3}$ in the Pekilo group. The results of the quantitative urine analyses are listed in Table 6. The allantoin and uric acid contents of samples from a single urination did not differ significantly in the two groups. The allantoin/creatinine ratio, on the other hand, was significantly higher $(\mathrm{P}<0.01)$ in the Pekilo than in the control group.

\section{Discussion}

In the present experiment the kind of protein supplement used in the diet - Pekilo or fish meal and soybean meal mixture - did not have a significant effect on the growth of pigs. In earlier feeding experiments the Pekilo used as protein supplement also had no significant growth-limiting effect in pigs (Alaviuhkola et al. 1975, Barber et al. 1977).

In the light of the results obtained in this experiment, the use of Pekilo biomass had no detrimental effect on the reproductive performance of the sows. The test material, however, was too small to allow any definite conclusion 
to be made on this point. Normally 10 per cent of the sows mating for the first time do not have oestrus and an additional 10 per cent of those with oestrus generally fail to conceive. In this experiment one animal out of 16 failed to become pregnant. The death rate among pigs born to both control and Pekilo sows falls within the normal mortaility range of $15-20$ per cent. The slightly faster growth rate of the Pekilo pigs during the suckling period was presumably due to the smaller average size of the litters in comparison to the control group.

Significant differences were not found between the Pekilo and control group sows with respect to blood haemoglobin, haematocrit, white cell count, serum ASAT and ALAT activities, bilirubin and protein contents and albumin/ globulin ratio. In a short-term feeding experiment with pigs FARSTAD et al. (1975) observed some differences in the blood values of animals receiving various amounts of Pekilo in their diet either with soybean protein or as the sole source of protein, as compared with animals given soybean protein alone; the values lie, however, within normal range for pigs. The serum urea level in the Pekilo group was lower than that in the control group. The result is similar in trend to that obtained by FARSTAD et al. (1975). Although a difference was seen between the plasma glucose contents of the Pekilo and control groups the values lie within normal limits.

The rather low serum uric acid contents of the swine were very close to the lowest limits of detection of the analysis method used. Uric acid, which is a product of nucleic acid metabolism, is metabolized further to allantoin in swine. Roth and KIRCHgEssner (1977) have demonstrated that serum allantoin content as well as excretion of allantoin and uric acid in urine increase in proportion to the amount of nucleic acid in the diet of pigs. However, the effect of nucleic acid content in the diet on the uric acid excretion of swine was rather small. In the present experiment the difference between allantoin contents in urine of the two groups was evident orly after the concentration differences between the urines were eliminated by relating the allantoin values to the urine creatinine values. The daily urine volume of swine may vary normally from two to six liters (CoRnelius and Kaneko 1963). In the absence of metabolic cages it was not possible to collect the 24hour urine from the animals. No difference was found between the urinary uric acid levels of the Pekilo and control groups; the values were dispersed over a wide range in both groups.

The $\mathrm{pH}$ and the mean urine density of the samples from both the Pekilo and the control animals corresponded to those normally encountered in swine (Cornelius and Kaneko 1963). The glucose present in the urine of a few animals may have been due to postprandial hyperglycaemia. The taking of urine samples could not be timed exactly.

This experiment gave information about the effects ot long-term feeding with comparatively small amounts of Pekilo biomass on some blood and urine parameters that give information about protein metabolism and the state of the liver and kidneys. The results obtained corroborate the results of short-term feeding experiments carried out earlier and indicate no detrimental effects. Further studies are needed to obtain evidence on the absence of such 
effects from the long-term use of Pekilo, especially with regard to possible carcinogenic, mutagenic and teratogenic effects.

Acknowledgements. This study was financially supported by the SITU Group, composed of representatives of several Finnish companies, mainly in the paper and pulp industry. The serum electrophoresis runs were made at the Biochemical Research Institute, Helsinki, with the assistance of Mr. Hannu Kalsta, Lic.Ph. We are grateful to Mr. Heikki Korpela, D.V.M., for expert advice at various stages of this work.

\section{REFERENCES}

Ahlström, A., Forss, K., Korvistornen, P. \& Lưdell, R. 1968. Eräiden sienilajien akuutin toksisuuden testaus rotilla. Proteiinin valmistus sulfiittiprosessin yhteydessä IV. Tutkimusselostus. 8 p. Oy Keskuslaboratorio Ab, Espoo.

- , JÄrvinen, R. \& Korvistornen, P. 1969. Sienimassojen ravintokelpoisuus, osa II. Ravintobiologinen arvo. Proteiinin valmistus sulfiittiprosessin yhteydessä IX. Tutkimusselostus. 40 p. Oy Keskuslaboratorio Ab, Espoo.

Alaviuhkola, T., Korhonen, I., Partanen, J. \& Lampila, M. 1975. Pekilo protein in the nutrition of growing-finishing pigs. Acta Agric. Scand. 25: 301-304.

ANON. 1974. Scandinavian standardizations of enzyme determination. Recommended methods for the determination of four enzymes in blood. Scand. J. Clin. Lab. Invest. 33: 287-306.

Barber, R., Braude, R. \& Mitchell, K. 1977. The value of $*$ Pekilo proteins for growing pigs. Anim. Feed Sci, Technol. 2: 161-169.

Clark, L. \& Thompson, H. 1949. Determination of creatine and creatinine in urine. An. Chem. 21: $1218-1221$.

Coles, E. 1967. Veterinary clinical pathology. 134 p. W. B. Saunders Company. Philadelphia and London.

Cornelius, C. \& Kanenko, J. 1963. Clinical biochemistry of domestic animals. 678 p. Academic Press, New York.

Farstad, L., Liven, E., Flatlandsmo, K. \& Naess, B. 1975. Effects of feeding *Pekilo» single cell protein in various consentrations to growing pigs. Acta Agric. Scand. 25: $291-300$,

FAwcetr, J. \& Scotr, J. 1960. A rapid and precise method for the determination of urea. J. Clin. Path. 13: 156-159.

FEHRNSTröm, H. \& MoBERg, U. 1977. SDS and conventional polyacrylamide gel electrophoresis with LKB 2117 Multiphor. 15 p. LKB-produkter AB Bromma, Sweden.

Forss, K. 1974. Pekilo-processen - en FoU-produkt från Central laboratorium Ab. Kem. Tidskr. 86(6): $34-39$.

Hyvärinen, A., Jännes, J., Nikkilï, E., Saris, N.-E. \& Voipıo, P. 1972. Kliiniset laboratoriotutkimukset. 581 p. WSOY. Porvoo-Helsinki.

JENDRAssik, L. \& Grof, P. 1938. Vereinfachte photometrische Methoden zur Bestimmung des Blutbilirubins. Biochem. Z. 297: 81-89.

Kageyama, N. 1971. A direct colorimetric determination of uric acid in serum and urine with uricase-catalase system. Clin. Chim. Acta 31:421-426.

KAMPEN, E. VAN \& Zijlstra, W. 1961. Standardization of hemoglobinometry. II. The hemiglobincyanide method. Clin. Chim. Acta 6: 538-544.

Kirskinen, T. (Ed.) 1979. Research reports of Pekilo-symposium, Tampere 12. - 15. 9. 1978. Agricultural Research Centre, Institute of Animal Husbandry, Report No. 12. Tikkurila.

LaKsesvela, B. \& Slagsvold, P. 1974. Experiments on Pekilo as a source of protein for young chicks, with particular reference to effects of supplementation with methionine and sulphates. Acta Agric. Scand. 24: 169-174.

Lampila, M., Korhonen, I. \& Partanen, J. 1971. Proteinin valmistus sulfiittiprosessin yhteydessä. Pekilo-proteiinituotteella Maatalouden tutkimuskeskuksessa suoritetut eläinkokeet. Tutkimusselostus. 37 p. Oy Keskuslaboratorio Ab, Espoo. 
PAG. 1972. PAG guideline for preclinical testing of novel sources of protein. PAG Guideline No. 6. 24 p.

Poutrainen, E. 1973. Pekilo-proteiini munivien kanojen ja broilereiden ruokinnassa. Siipikarja 9: 247-255.

Romantschuк, H. 1975. The Pekilo process: protein from spent sulfite liquor. In: Singlecell protein II. p. 344-356. Eds. Tannenbaum, S. \& Wang, D. The MIT Press, Cambridge, Massachusetts and London.

Roth, F. \& Kirchgessner. M. 1977. Zum Einfluss steigender Mengen alimentär zugeführter Ribonucleinsãyre auf den N-Stoffwechsel beim Ferkel. Z. Tierphysiol., Tierernährg. u. Futtermittelkde. 38: 214-225.

Salo, M.-L. 1977. The carbohydrate composition and solubility of Pekilo protein and two yeasts. Acta Agric. Scand. 27: 77-80.

- 1979. Chemical composition and feed value of the Pekilo. In: Research reports of Pekilosymposium, Tampere 12. - 15. 9. 1978. p. 9-20. Ed. Kiiskinen, T. Agricultural Research Centre, Institute of Animal Husbandry, Report No. 12. Tikkurila.

Schalm, O., Jain, N. \& Carroll, E. 1975. Veterinary hematology. 3rd ed. 85 p. Lea \& Febiger. Philadelphia.

Sснмпрт, F. 1961. Die enzymatische Bestimmung von Glucose und Fructose nebeneinander. Klin. Wschr. 39: 1244-1247.

Stevens, J. 1975. Chart of normal values for the cat, dog, horse, cow, sheep and pig. Minn. Veter. 15: 16-22.

Sumi, T., Umeda, Y., Kishi, Y. ,Какімото, F. \& ТАканаSHI, K. 1976. A spectrofluorometric method for determining plasma allantoin based on the glyoxylate reductase reaction. Anal. Biochem. 75: 563-567.

Weichselbaum, T. 1946. An accurate and rapid method for the determination of proteins in small amounts of blood serum and plasma. Am. J. Clin. Path. 16:40-49.

Ms received August 30, 1979.

\title{
SELOSTUS
}

\section{Tutkimus pekilo-yksisoluproteiinin fysiologisista vaikutuksista sioissa}

\author{
Ritva Järvinen, Raija Savonen, Antti Ahlström \\ Helsingin yliopiston ravitsemustieteen laitos, 00710 Helsinki 71
}

Trmo Alaviuhrola

Maatalouden tutkimuskeskus, Sikatalouskoeasema, 05840 Hyvinkää 4

Työssä tutkittiin sulfiittiselluloosan jäteliemessä kasvatetun pekilomassan (Paecilomyces varioti) fysiologisia vaikutuksia sioissa.

Koe-eläiminä oli 16 maatiaisrotuista, kokeen alussa noin 22 kg:n painoista emakkoporsasta kahdessa kahdeksan yksilön ryhmässä (Maatalouden tutkimuskeskuksen Sikatalouskoeasema, Hyvinkää). Eläimiä ruokittiin ohra- ja kaurapohjaisella vitamiineilla ja kivennäisaineilla täydennetyllä rehulla. Vertailuryhmän rehussa lisävalkuaislähteenä käytetty soijan ja kalajauhon seos korvattiin koeryhmän rehussa $13 \%$ :lla pekiloa. Imetysaikana pekilon määrä koeryhmän rehussa oli $15 \%$. Koeaika oli noin vuosi, johon sisältyi kasvukausi, tiineysaika ja imetysaika.

Eläinten rehunkulutusta ja painonkehitystä seurattiin. Lisääntymistuloksesta tehtiin havainnot. Porsaiden vieroituksen jälkeen määritettiin emakoiden verestä hemoglobiini, hamotokriitti ja laskettiin valk'z̧njoso Plasmasta analysoitiin glukoosi ja seerumista bilirubiini, ASAT, ALAT, urea, virtsahappo, allantoiini, kokonaisproteiini sekä albumiini/globuliini -suhde. Kertavirtsanäytteestä määritettiin allantoiini, virtsahappo ja kreatiniini kvantitatiivisesti sekä $\mathrm{pH}$, glukoosi ja proteiini puolikvantitatiivisesti ja ominaispaino. 
Eläinten painonkehityksessä, rehunkulutuksessa, rehun hyväksikäytössä ja lisääntymisessä ei ollut merkitseviä eroja koeryhmien välillä. Pekiloa saaneiden eläinten seerumin ureapitoisuus ja plasman glukoosipitoisuus olivat merkitsevästi pienempiä kuin vertailuryhmässä, mutta pitoisuudet olivat kuitenkin normaaliarvojen rajoissa. Pekiloryhmän seerumin allantoiinipitoisuus ja virtsan allantoiini/kreatiiniini -suhde olivat merkitsevästi suurempia kuin vertailuryhmässä. Muissa veri- ja virtsa-analyyseissä ei todettu eroja ryhmien välillä.

Pienehköllä pekilomäärällä siitossikojen ruokaan lisättynä ei todettu olevan noin vuoden kestäneessä kokeessa haitallisia vaikutuksia eläinten kasvun, rehunkulutuksen, rehun hyväksikäytồn, lisääntymisen sekä tiettyjen veri- ja virtsa-arvojen perusteella. 